\title{
Salicola marasensis gen. nov., sp. nov., an extremely halophilic bacterium isolated from the Maras solar salterns in Peru
}

\author{
Lenin Maturrano, ${ }^{1}$ María Valens-Vadell, ${ }^{2}$ Ramon Rosselló-Mora ${ }^{2}$ \\ and Josefa Antón ${ }^{1}$ \\ 'División de Microbiología, Departamento de Fisiología, Genética y Microbiología, \\ Universidad de Alicante, E-03080 Alicante, Spain \\ ${ }^{2}$ Institut Mediterrani d'Estudis Avançats (CSIC-UIB), C/Miquel Marqués 21, E-07190 Esporles, \\ Mallorca, Illes Balears, Spain
}

Correspondence

Ramon Rosselló-Mora rossello-mora@uib.es

\begin{abstract}
Six strains of extremely halophilic bacteria were isolated from several crystallizer ponds of the Maras solar salterns in the Peruvian Andes. On the basis of 16S rRNA gene sequence similarity, $\mathrm{G}+\mathrm{C}$ contents and DNA-DNA hybridization results, the six isolates constituted a genomically homogeneous group affiliated with the Gammaproteobacteria. The closest relatives were members of the halophilic genera Halovibrio and Halospina, which showed 16S rRNA gene sequence similarities below $97 \%$ and whole-genome hybridization levels below $33 \%$ for the type strain, $7 \mathrm{Sm} 5^{\top}$. From the genomic and phenotypic properties of the six novel isolates and phylogenetic reconstruction based on $16 \mathrm{~S}$ rRNA gene sequence analysis, they can be considered to represent a novel genus within the Gammaproteobacteria. On the basis of the taxonomic study, a novel genus, Salicola gen. nov., is proposed containing the single species Salicola marasensis sp. nov., which is the type species. The type strain of Salicola marasensis is $7 \mathrm{Sm} 5^{\top}\left(=\right.$ CECT $7107^{\top}=\mathrm{CIP}$ $108835^{\mathrm{T}}$ ).
\end{abstract}

Until the description of the genus Salinibacter, only haloarchaea were considered to be of ecological relevance in solar salterns (Antón et al., 2000). The classification of Salinibacter ruber as a novel species within the phylum Bacteroidetes (Antón et al., 2002) extended the short list of extremely halophilic members of the Bacteria. There are not many characterized members of this domain able to grow under such extreme conditions [only some members of the family Ectothiorhodospiraceae of the Proteobacteria, some members of the Firmicutes (Halanaerobiaceae and Bacillaceae) and some members of the Actinobacteria], but, in all, no more than 11 genera are represented (Oren, 2002). However, only species of the genus Salinibacter have been reported to thrive abundantly in crystallizer ponds of solar salterns (Antón et al., 2002).

Hypersaline environments can be classified as thalassohaline or athalassohaline: thalassohaline water is concentrated seawater with $\mathrm{NaCl}$ as the major salt, while athalassohaline water is saline water that is rich in anions other than chloride

The GenBank/EMBL/DDBJ accession numbers for the 16S rRNA gene sequences of strains $7 \mathrm{Sm} 5^{\top}, 2 \mathrm{Sb} 7,7 \mathrm{Sa} 10,7 \mathrm{Sm} 7,7 \mathrm{Mb} 1$ and 5Ma3 are DQ019934, D0019935 and D0087259-D0087262, respectively.

Details of the reference sequences used in the construction of Fig. 1 are available as supplementary material in IJSEM Online. and/or cations other than sodium (Oren, 2002). The Maras solar salterns are located at $3380 \mathrm{~m}$ above sea level in the heart of the Peruvian Andes (Cusco Region), and they have been exploited for more than 500 years (Basadre, 1969). Brines are produced from the dissolution of the surrounding rocks of the Maras formation, and their composition can be considered as thalassohaline (Maturrano et al., 2006). These salterns have been studied using culture-independent molecular methods to reveal the structure of the indigenous microbial community. Additionally, enrichment cultures of heterotrophic halophilic micro-organisms have been performed in order to obtain more information about the heterotrophic culturable fraction of the microbial population (Maturrano et al., 2006).

During the enrichment and isolation procedure of several Maras brine samples, six Gram-negative, heterotrophic strains were isolated. Here, we report the taxonomic characterization of these six isolates, which could be considered as relevant representatives of the bacterial fraction of the natural microbial community thriving in these environments (Maturrano et al., 2006). Together, the results showed that the six strains formed a monophyletic and genomically and phenotypically coherent group. Their closest relatives are the members of the genera Halovibrio and Halospina (Sorokin et al., 2006) and strain DSM 3050, which was described as the type strain of Pseudomonas 
halophila (Fendrich, 1988). The position of strain DSM 3050 is currently being re-evaluated because this strain may answer the description of Halovibrio variabilis (Sorokin \& Tindall, 2006) rather than its original description (Fendrich, 1988). On the basis of the results of our taxonomic study and previous characterizations of the most closely related genera, we consider that the six Peruvian strains should be included within a novel genus and species within the Gammaproteobacteria.

For the isolation of halophilic prokaryotes, two different media were used: SW medium (containing the following, in $\mathrm{g} \mathrm{l}^{-1}: \mathrm{NaBr}, 0 \cdot 65 ; \mathrm{NaHCO}_{3}, 0 \cdot 167 ; \mathrm{KCl}, 5 \cdot 0 ; \mathrm{CaCl}_{2}, 0 \cdot 723$; $\mathrm{MgSO}_{4} \cdot 7 \mathrm{H}_{2} \mathrm{O}, 49 \cdot 492 ; \mathrm{MgCl}_{2} \cdot 6 \mathrm{H}_{2} \mathrm{O}, 34 \cdot 567 ; \mathrm{NaCl}, 195 \cdot 0$; $\mathrm{pH} 7 \cdot 0$ ); and MS medium, designed for this work (containing the following, in $\mathrm{g} \mathrm{l}^{-1}: \mathrm{NaBr}, 0 \cdot 128 ; \mathrm{NaHCO}_{3}, 0 \cdot 14 ; \mathrm{KCl}$, $0 \cdot 95 ; \mathrm{CaCl}_{2}, 3 \cdot 32 ; \mathrm{NaCl}, 234 \cdot 0 ; \mathrm{pH} 7 \cdot 2$ ). In both cases, the medium was supplemented with different concentrations of yeast extract $(0 \cdot 1,0 \cdot 2$ and $0.5 \%)$ and incubated at $37^{\circ} \mathrm{C}$ for at least 4 weeks. Solid media were prepared by adding agar to a final concentration of $1.5 \%$ prior to sterilization. Brines were plated directly onto the different media without prior enrichment.

To determine $\mathrm{pH}$, salinity and temperature growth ranges, SW medium with $0 \cdot 2 \%$ yeast extract was used. Isolates were grown, in triplicate, with increasing levels of $\mathrm{NaCl}(0,5,10$, $15,20,25,30 \%$ and up to saturation), at increasing $\mathrm{pH}$ $(\mathrm{pH} 5 \cdot 0,6 \cdot 0,6 \cdot 5,7 \cdot 0,8 \cdot 0$ and $9 \cdot 0)$ and at increasing temperatures $\left(15,20,25,30,35,40,45\right.$ and $\left.50{ }^{\circ} \mathrm{C}\right)$. Temperature and $\mathrm{pH}$ tests were performed in SW medium containing $15 \%$ salt $(15 \% \mathrm{SW})$ and $0 \cdot 2 \%$ yeast extract. In all cases, growth was assessed by observing increases in optical density at $600 \mathrm{~nm}$ up to the stationary phase.

Cell biomass for enzyme testing and macromolecule extraction was also obtained after growth on SW medium containing $15 \%$ salt and $0 \cdot 2 \%$ yeast extract. Gram staining was performed using a protocol adapted for halophilic organisms (Dussault, 1955). Catalase activity was determined by adding $10 \%(\mathrm{v} / \mathrm{v}) \mathrm{H}_{2} \mathrm{O}_{2}$ and observing its hydrolysis and the consequent gas formation (Bradshaw, 1992). Oxidase activity was determined with Oxoid BR644 indicator sticks. Denitrification was analysed by growing the strains in SW medium containing $15 \%$ salt and $0 \cdot 2 \%$ yeast extract and supplemented with $0.5 \% \mathrm{NaNO}_{3}$. Gas formation was observed from its accumulation in Durham tubes. Nitrite formation, gelatinase, amylase, casein hydrolysis and the presence of poly- $\beta$-hydroxybutyrate were assayed according to the protocols of Smibert \& Krieg (1981). Enzyme assays for arginine dihydrolase, lysine decarboxylase, urease and ornithine decarboxylase were performed by following the protocols of Baumann \& Baumann (1981). Voges-Proskauer and methyl red assays were performed by modifying the medium by using a salt concentration of $15 \%$ (Smibert \& Krieg, 1981). Indole production was assayed in $15 \%$ SW supplemented with tryptophan and by adding Kovács' indole reagent (Holding \& Colle, 1971). Motility and $\mathrm{H}_{2} \mathrm{~S}$ production were assayed on Oxoid SIM medium. Glucose fermentation, gas production, aesculin hydrolysis and $\beta$-galactosidase were determined using the API 20NE system (bioMérieux). Carbohydrate utilization was analysed in triplicate by means of growth in $15 \%$ SW supplemented with each of the carbohydrates at different concentrations $\left(0 \cdot 5,1 \cdot 0\right.$ and $\left.5 \cdot 0 \mathrm{~g} \mathrm{l}^{-1}\right)$, as described by Fendrich (1988). Cellular fatty acid profiles were estimated by GC performed at the Identification Service Laboratories of the Deutsche Sammlung von Mikroorganismen und Zellkulturen (Braunschweig, Germany). Cells were grown in SW medium containing $15 \%$ salt and with $0 \cdot 2 \%$ yeast extract as the sole carbon and energy source. Cell morphology, size and flagellation were determined by observation by electron microscopy after negative staining of cells with $1 \%$ phosphotungstic acid (RossellóMora et al., 1993).

Complete 16S rRNA gene sequences were compared initially with reference sequences of the $\mathrm{nr}$ (formerly 'non-redundant') database at the National Center for Biotechnology Information (http://www.ncbi.nlm.nih.gov) using BLAST (Altschul et al., 1997). New 16S rRNA gene sequences were then added to an alignment of about 50000 homologous bacterial 16S rRNA gene primary structures as implemented by the ARB software package, and corresponding to the released database available at http://www. arb-home.de (Ludwig et al., 2004). Phylogenetic analyses were performed by the use of different datasets and by the use of the three different algorithms (neighbour joining, maximum parsimony and maximum likelihood) as implemented by the ARB software package. Finally, a consensus tree was constructed after the evaluation of the trees resulting from the use of different algorithms and datasets, as previously recommended (Ludwig et al., 1998).

Genomic DNA was prepared according to the method of Marmur (1961). The G $+\mathrm{C}$ content was analysed by hydrolysis of DNA to its nucleosides, and was quantified by HPLC according to the method reported by Peña et al. (2005). DNA-DNA hybridization experiments were carried out by using a non-radioactive, microtitre plate method (Ziemke et al., 1998).

Samples from three different crystallizer ponds were inoculated onto two different media (SW and MS) with increasing yeast extract concentrations $(0 \cdot 1,0 \cdot 2$ and $0 \cdot 5 \%)$. Of all the colonies that grew on these plates, six pure cultures were selected for taxonomic characterization because of their phylogenetic coherence and their relevance to the environment in which they thrived. The phenotypic properties shared by the six isolates and details of the isolation media are listed in Table 1. In all cases, colonies were nonpigmented (slightly beige) and mucoid with smooth edges when grown on $15 \% \mathrm{SW}$ with $0 \cdot 2 \%$ yeast extract. The cells of all isolates were rods about $1 \mu \mathrm{m}$ long and $0.5 \mu \mathrm{m}$ wide and were motile by means of single polar flagella. All of the isolates were extremely halophilic: no growth was observed in culture media with $\mathrm{NaCl}$ concentrations below $10 \%$. Strains were able to grow at $\mathrm{NaCl}$ concentrations up to $30 \%$, 
Table 1. Differential phenotypic characteristics among the six novel Peruvian strains (Salicola gen. nov.)

All strains showed a strict dissimilatory metabolism with oxygen as the sole electron acceptor, whereas no fermentation or nitrate respiratory pathway was detected. All were Gram-negative and motile by means of single polar flagella. All strains were positive for cytochrome $c$ oxidase, catalase, urease, gelatin liquefaction, phenylalanine deaminase, $\beta$-galactosidase, arginine dihydrolase and lysine decarboxylase. All were positive for the use of the following substrates as sole carbon and energy sources: fructose, galactose, glucose, arabinose, cellobiose, maltose, mannose, sucrose, trehalose, xylose, acetate, citrate, pyruvate, succinate, propionate, aesculin, ethanol, glycerol, caproate, glutamine, lactose, mannitol and sorbitol. All strains were negative for starch hydrolysis, indole production, sulphide production and ornithine decarboxylase and for growth with salicin, lactate, butyrate, caprylate, formate, malate, pelargonate and valerate as sole carbon sources.

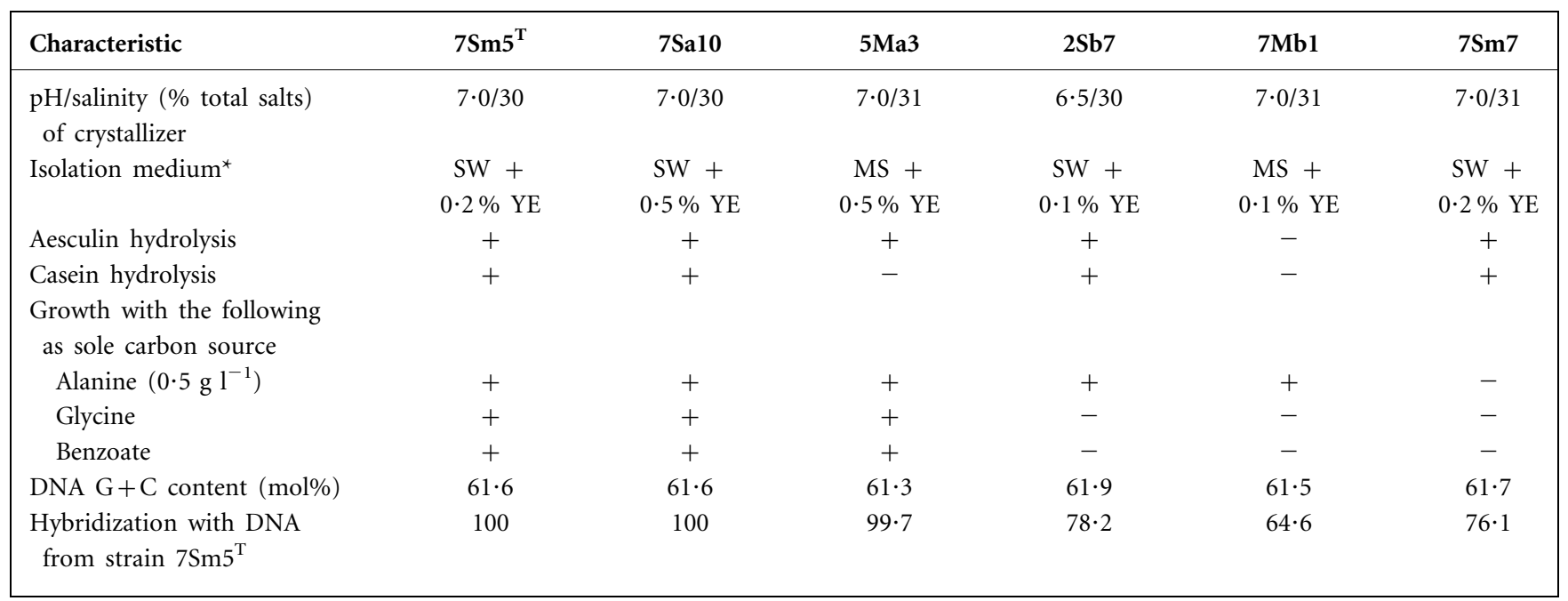

${ }^{\star}$ YE, Yeast extract.

with an optimum at $15 \%$ (Table 2 ). The optimal temperature for growth was about $35^{\circ} \mathrm{C}$ and the optimal $\mathrm{pH}$ was 7.

16S rRNA gene sequence phylogenetic analysis (Fig. 1) showed this set of strains to be a monophyletic group that shared internal sequence similarity values of more than $99 \%$. The most closely related cultured strains known were Halospina denitrificans HGD 1-3 ${ }^{\mathrm{T}}$ (DQ072719), Halovibrio denitrificans HGD $3^{\mathrm{T}}$ (DQ072718) and [P. halophila] DSM $3050^{\mathrm{T}}$ (AB021383), with rRNA gene similarity values ranging from $95 \cdot 5$ to $96 \cdot 9 \%$. All of them formed a stable cluster of sequences representing halophilic isolates. The whole group of Maras sequences can be regarded as an independent branch within this clade of halophilic species (Fig. 1), since all treeing approaches showed the sequences as a single independent branch. We could not resolve the branching order of the neighbouring genera with respect to the clade of halophiles. However, and in contrast to the tree reported by Sorokin et al. (2006), we could not confirm Marinobacter as the closest relative. In our case, all of the related genera showed incongruent branching patterns that varied depending on the treeing approach used or the dataset used. The branching orders that could not be resolved were drawn as multifurcations, as recommended by Ludwig et al. (1998). However, all of the bifurcations shown in the tree appeared to be stable independently of the algorithm, dataset or mask used in the analysis.
The genomic traits represented by $\mathrm{G}+\mathrm{C}$ content and DNA-DNA reassociation indicated that the six novel isolates also constituted a homogeneous genomic group (Table 1). The strains had nearly identical $\mathrm{G}+\mathrm{C}$ contents in the range $61 \cdot 3-61 \cdot 7 \mathrm{~mol} \%$, and the DNA of each of them reassociated with strain $7 \mathrm{Sm} 5^{\mathrm{T}}$ at values above $64 \cdot 6 \%$. The three most closely related strains, DSM $3050^{\mathrm{T}}$, HGD $1-3^{\mathrm{T}}$ and $\mathrm{HGD} 3^{\mathrm{T}}$, which represented the phylogenetically closest genera, gave hybridization results of $33 \cdot 1,31 \cdot 6$ and $25 \cdot 7 \%$, respectively. The pooled standard deviation of the experiments was $1 \%$.

The six extremely halophilic strains from Maras shared a homogeneous phenotype but showed some intraspecific diversity (Table 1). All members of this phylogenetic branch showed positive reactions for cytochrome $c$ oxidase, catalase, urease, gelatinase, $\beta$-galactosidase and phenylalanine decarboxylase, as well as for a large number of compounds that could serve as primary substrates for growth (Table 1). Additionally, the members of this phylogenetic branch harbouring extreme halophiles could be differentiated from the most closely related genera by means of traits such as type of motility, ability to hydrolyse gelatin and urea, inability to respire nitrate and hydrolyse starch and by the ability to use carbohydrates (Table 2). Intraspecifically, the group of extremely halophilic, Peruvian strains differed in traits such as aesculin and casein hydrolysis and by the use of alanine, glycine and benzoate. 
Table 2. Differential phenotypic characteristics of the novel Peruvian isolates (Salicola gen. nov.) and members of closely related genera

Data for reference taxa were taken from the following studies: Halovibrio [Fendrich, 1988 (isolate III); Sorokin et al., 2006], Halospina (Sorokin et al., 2006), Halomonas (Vreeland, 2005), Microbulbifer (González, 2005), Marinobacter (Bowman \& McMeekin, 2005) and Alcanivorax (Golyshin et al., 2005). \pm , Variable; NR, not reported.

\begin{tabular}{|c|c|c|c|c|c|c|c|}
\hline Characteristic & Salicola & Halovibrio & Halospina & Halomonas & Microbulbifer & Marinobacter & Alcanivorax \\
\hline Cell morphology & Rod & $\begin{array}{c}\text { Vibrioid or } \\
\text { short spirillum }\end{array}$ & Rod & Rod & Rod & Rod & Rod \\
\hline Flagella & Polar & Polar & Non-motile & $\begin{array}{l}\text { Peritrichous, } \\
\text { polar or none }\end{array}$ & None & $\begin{array}{l}\text { None } \\
\text { or polar }\end{array}$ & $\begin{array}{l}\text { None } \\
\text { or polar }\end{array}$ \\
\hline Optimal temperature for growth $\left({ }^{\circ} \mathrm{C}\right)$ & 35 & 33 & NR & 30 & 37 & 30 & $20-30$ \\
\hline Salinity range for growth (\%) & $10-30$ & $7-27$ & $11 \cdot 5-29$ & $3-32$ & $0 \cdot 5-5 \cdot 8$ & $3-20$ & $1-12 \cdot 5$ \\
\hline Optimal salinity for growth (\%) & 15 & 9 & $14 \cdot 5-17 \cdot 5$ & $3-8$ & $0 \cdot 5-3$ & $3-6$ & $3-5$ \\
\hline Denitrification & - & - & + & \pm & - & + & - \\
\hline $\mathrm{NO}_{2}^{-}$production from $\mathrm{NO}_{3}^{-}$ & - & + & + & \pm & - & + & + \\
\hline Arginine dihydrolase & + & - & NR & - & NR & - & - \\
\hline Ornithine decarboxylase & - & - & NR & + & NR & - & - \\
\hline Lysine decarboxylase & + & - & NR & + & NR & - & - \\
\hline Gelatin liquefaction & + & - & NR & \pm & + & - & - \\
\hline Starch hydrolysis & - & NR & NR & - & + & - & - \\
\hline Urease & + & + & NR & \pm & NR & - & - \\
\hline Carbohydrate utilization & + & - & - & + & + & - & - \\
\hline DNA G $+\mathrm{C}$ content $(\mathrm{mol} \%)$ & $61 \cdot 3-61 \cdot 9$ & $61-61 \cdot 8$ & 60 & $50-61$ & $57 \cdot 6$ & 53 & $53-66$ \\
\hline
\end{tabular}

Finally, all of the fatty acid profiles of the Peruvian isolates were very similar (Table 3 ), having $\mathrm{C}_{12: 0} 3-\mathrm{OH}, \mathrm{C}_{16: 0}$, $\mathrm{C}_{18: 1} \omega 9 c$ and $\mathrm{C}_{18: 0} 10$-methyl as the major components.
The similar features are in accordance with previously reported profiles for closely related strains (Sorokin et al., 2006). However, the Peruvian isolates can be differentiated

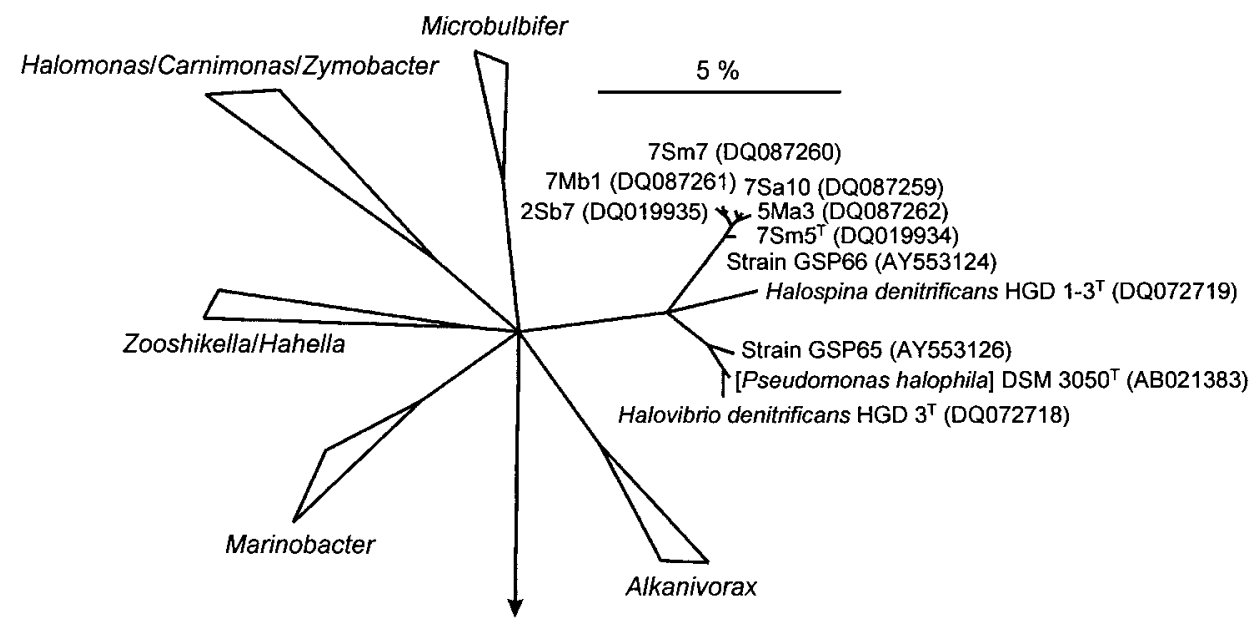

Fig. 1. Phylogenetic reconstruction based on a neighbour-joining calculation. The tree was modified after multiple analysis of different datasets and by the use of maximum-parsimony, neighbour-joining and maximum-likelihood algorithms. To reconstruct the phylogeny and resolve branching patterns, the different datasets were analysed by using all homologous positions in the alignment, by using consensus masks that removed all the non-conserved indels of the domain Bacteria or by using maximumfrequency masks that removed highly variable positions within the Gammaproteobacteria, as implemented by the ARB datafile. The resulting tree shows a consensus topology where multifurcations indicate those branching orders that could not be resolved unambiguously. In this tree, representative members of the genera Halomonas, Carnimonas, Zymobacter, Alcanivorax, Marinobacter, Zooshikella, Hahella and Microbulbifer appear hidden within their respective phylogenetic clades. Details of the sequences used are given in Supplementary Table S1 in IJSEM Online. Bar, $5 \%$ sequence divergence. 
Table 3. Fatty acid profiles of the novel Peruvian strains (Salicola gen. nov.) and some closely related strains

Data were obtained in this study or were taken from Sorokin et al. (2006) (for Halovibrio denitrificans HGD $3^{\mathrm{T}}$ and Halospina denitrificans HGD $\left.1-3^{\mathrm{T}}\right)$. Values are percentages of total fatty acids; - , not detected.

\begin{tabular}{|c|c|c|c|c|c|c|c|c|c|}
\hline Fatty acid & $7 \mathrm{Sm} 5^{\mathrm{T}}$ & 7Sa10 & $5 \mathrm{Ma} 3$ & $2 \mathrm{Sb} 7$ & $7 \mathrm{Mb1}$ & $7 \mathrm{Sm} 7$ & $\begin{array}{c}{[\text { P. halophila }]} \\
{\text { DSM } 3050^{\mathrm{T}}}\end{array}$ & $\begin{array}{c}\text { Halovibrio } \\
\text { denitrificans } \\
\text { HGD } 3^{T}\end{array}$ & $\begin{array}{c}\text { Halospina } \\
\text { denitrificans } \\
\text { HGD } 1-3^{T}\end{array}$ \\
\hline$C_{12: 0}$ & $1 \cdot 53$ & $1 \cdot 26$ & $1 \cdot 18$ & $1 \cdot 96$ & $1 \cdot 87$ & $1 \cdot 84$ & $1 \cdot 41$ & - & $1 \cdot 17$ \\
\hline $\mathrm{C}_{12: 0} 3-\mathrm{OH}$ & $5 \cdot 77$ & $5 \cdot 21$ & $7 \cdot 46$ & $8 \cdot 29$ & $7 \cdot 63$ & $7 \cdot 37$ & $8 \cdot 95$ & $3 \cdot 35$ & $3 \cdot 36$ \\
\hline $\mathrm{C}_{14: 1} 3-\mathrm{OH}$ & - & - & - & - & - & - & - & - & $1 \cdot 06$ \\
\hline$C_{16: 0}$ & $15 \cdot 81$ & $15 \cdot 92$ & $16 \cdot 69$ & $14 \cdot 68$ & $14 \cdot 79$ & $15 \cdot 30$ & $10 \cdot 06$ & $15 \cdot 40$ & $7 \cdot 98$ \\
\hline $\mathrm{C}_{16: 1^{*}}$ & - & - & - & - & - & - & - & - & $1 \cdot 47$ \\
\hline $\mathrm{C}_{16: 1} \omega 9 c$ & $2 \cdot 26$ & $2 \cdot 25$ & $2 \cdot 20$ & $2 \cdot 66$ & $2 \cdot 63$ & $2 \cdot 47$ & $3 \cdot 32$ & $3 \cdot 20$ & - \\
\hline $\mathrm{C}_{16: 1} \omega 7 c$ & - & - & - & - & - & - & - & $5 \cdot 22$ & - \\
\hline $\mathrm{C}_{18: 1} \omega 7 c$ & - & - & - & - & - & - & $0 \cdot 44$ & $10 \cdot 18$ & - \\
\hline $\mathrm{C}_{18: 1} \omega 5 c$ & - & - & - & - & - & - & $0 \cdot 19$ & - & - \\
\hline $\mathrm{C}_{18: 0}$ & $8 \cdot 50$ & $8 \cdot 83$ & $8 \cdot 21$ & $8 \cdot 82$ & $8 \cdot 86$ & $8 \cdot 46$ & $3 \cdot 13$ & $3 \cdot 32$ & $5 \cdot 45$ \\
\hline $\mathrm{C}_{18: 0}$ 10-methyl & $21 \cdot 55$ & $19 \cdot 91$ & $18 \cdot 0$ & $19 \cdot 25$ & $23 \cdot 30$ & $24 \cdot 15$ & $6 \cdot 49$ & $2 \cdot 01$ & - \\
\hline $\mathrm{C}_{18: 0} 2-\mathrm{OH}$ & - & - & - & - & - & - & $0 \cdot 34$ & - & - \\
\hline
\end{tabular}

${ }^{\star}$ The exact location of the double bond was not determined.

from representatives of the most closely related genera (DSM $3050^{\mathrm{T}}$, HGD $1-3^{\mathrm{T}}$ and HGD $3^{\mathrm{T}}$ ) by their relatively high $\mathrm{C}_{18: 0}$ 10-methyl content.

The six extremely halophilic isolates from Maras were shown to be a monophyletic set of individuals with enough phenotypic and genetic coherence to be considered as an independent taxon with respect to their closest relatives (Rosselló-Mora \& Amann, 2001; Stackebrandt et al., 2002). The strains analysed were isolated from different crystallizer ponds, which indicates both that they might correspond to different populations and that they may represent an important fraction of the prokaryotes inhabiting Maras' brines. Indeed, this hypothesis was corroborated by cultureindependent techniques, since members of this group were found, by fluorescence in situ hybridization analysis, to be the most abundant members of the Bacteria in the brines (Maturrano et al., 2006). Although 16S rRNA gene sequence analysis of the novel strains revealed a high degree of sequence similarity, the strains differed from each other in terms of genome content, as was demonstrated by the different DNA-DNA hybridization values obtained. Phylogenetically related strains have been isolated recently in similar environments, but they did not constitute an important fraction in relation to the total microbiota cultured at the same time (Caton et al., 2004). Additionally, it seems that relatives of $[P$. halophila $]$ could enhance growth of Walsby's square archaeon when co-cultured under laboratory conditions (Bolhuis et al., 2004). All of these data are indications that members of this phylogenetic branch may be relevant in their own environments.

Together, the data indicate that the six extremely halophilic isolates from Maras can be regarded as representing a single species independent of Halovibrio and Halospina species (Fendrich, 1988; Sorokin et al., 2006). In view of the way in which novel genera have been classified, our observations lead us to include the novel species within a novel genus, Salicola gen. nov. We propose the binomial Salicola marasensis sp. nov. for the novel group of extremely halophilic organisms isolated from crystallizer ponds of the Maras solar salterns in the Peruvian Andes, as they may be the most abundant and representative bacterial heterotrophs in this Andean environment.

\section{Description of Salicola gen. nov.}

Salicola (Sa.li' co.la. L. n. sal, salis salt, salt water, brine; L. masc. suff. - cola from L. n. incola an inhabitant; N.L. masc. n. Salicola an inhabitant of brine).

Rod-shaped bacteria, motile by means of single polar flagella. Phylogenetically affiliated to the Gammaproteobacteria. Gram-negative, strictly aerobic, heterotrophic, oxidase-, catalase-, urease-, phenylalanine decarboxylase-, $\beta$-galactosidase- and gelatinase-positive and able to use carbohydrates. Inhabitants of highly saline habitats such as salt lakes, 
saltern ponds and salt flats; in general, optimum growth occurs at salt concentrations above $14 \%(\mathrm{w} / \mathrm{v})$. Major fatty acids of the genus are $\mathrm{C}_{12: 0} 3-\mathrm{OH}, \mathrm{C}_{16: 0}, \mathrm{C}_{18: 1} \omega 9 c$ and $\mathrm{C}_{18: 0}$ 10-methyl. The latter fatty acid distinguishes Salicola species from the most closely related genera. The DNA $\mathrm{G}+\mathrm{C}$ content of members of the genus ranges between $61 \cdot 3$ and $61.9 \mathrm{~mol} \%$. The type species of the genus is Salicola marasensis.

\section{Description of Salicola marasensis sp. nov.}

Salicola marasensis (ma.ra.sen'sis N.L. masc. adj. marasensis pertaining to Maras, a region of the Peruvian Andes, where the first strains were isolated).

Cells are straight rods, motile by means of single polar flagella. Gram-negative. Extremely halophilic with an optimum $\mathrm{NaCl}$ requirement (in medium) of $15 \%$, though growth has been reported at $\mathrm{NaCl}$ concentrations up to $30 \%$. No growth is observed below $10 \% \mathrm{NaCl}$. The temperature optimum for growth is $35^{\circ} \mathrm{C}$. Strictly aerobic with a chemo-organotrophic metabolism; able to use carbohydrates as sole carbon and energy sources. Members of this species can be distinguished from other related species by their extreme halophily, by their temperature optimum and by their arginine dihydrolase and lysine decarboxylase activities. $\mathrm{pH}$ for growth ranges from $6 \cdot 0$ to $8 \cdot 0$, with an optimal $\mathrm{pH}$ of $7 \cdot 0$. Among the major fatty acids observed for the genus, $\mathrm{C}_{16: 0}$ and $\mathrm{C}_{18: 0}$ 10-methyl predominate over $\mathrm{C}_{12: 0} 3-\mathrm{OH}$ and $\mathrm{C}_{18: 1} \omega 9 c$. The DNA $\mathrm{G}+\mathrm{C}$ content is $61 \cdot 3-61 \cdot 9 \mathrm{~mol} \%$

The type strain, strain $7 \mathrm{Sm} 5^{\mathrm{T}}\left(=\mathrm{CECT} \quad 7107^{\mathrm{T}}=\mathrm{CIP}\right.$ $\left.108835^{\mathrm{T}}\right)$, was isolated from one of the saltern crystallizer ponds at Maras in the Peruvian Andes, and was one of the most representative inhabitants of these ponds.

\section{Acknowledgements}

The authors want to thank Brian Tindall of the Deutsche Sammlung von Mikroorganismen und Zellkulturen for providing type-strain cell material for DNA extraction, Jean Euzéby for invaluable help with the formation of names and Wolfgang Ludwig for maintaining a curated ARB database. The authors' research is funded by the following projects: BIO2000-005-P4-04 and BOS-2003-05198-C02-01 and BOS-200305198-C02-02 of the Spanish Ministry of Science and Education, grant GRUPOS03/137 from the Generalitat Valenciana and the network of excellence Marine Genomics Europe (GOCE-CT-505403) of the European Union.

\section{References}

Altschul, S. F., Madden, T. L., Schäffer, A. A., Zhang, J., Zhang, Z., Miller, W. \& Lipman, D. J. (1997). Gapped BLAST and PSI-BLAST: a new generation of protein database search programs. Nucleic Acids Res 25, 3389-3402.

Antón, J., Rosselló-Mora, R., Rodríguez-Valera, F. \& Amann, R. (2000). Extremely halophilic Bacteria in crystallizer ponds from solar salterns. Appl Environ Microbiol 66, 3052-3057.
Antón, J., Oren, A., Benlloch, S., Rodríguez-Valera, F., Amann, R. \& Rosselló-Mora, R. (2002). Salinibacter ruber gen. nov., sp. nov., a novel, extremely halophilic member of the Bacteria from saltern crystallizer ponds. Int J Syst Evol Microbiol 52, 485-491.

Basadre, J. (1969). Historia del Perú. Lima: San Marcos (in Spanish). Baumann, P. \& Baumann, L. (1981). The marine Gram-negative eubacteria: genera Photobacterium, Beneckea, Alteromonas, Pseudomonas and Alcaligenes. In The Prokaryotes, pp. 1302-1330. Edited by M. P. Starr, H. Stolp, H. G. Trüper, A. Balows \& H. G. Schlegel. Berlin: Springer.

Bolhuis, H., Te Poele, E. M. \& Rodríguez-Valera, F. (2004). Isolation and cultivation of Walsby's square archaeon. Environ Microbiol 6, 1287-1291.

Bowman, J. P. \& McMeekin, T. A. (2005). Genus VII. Marinobacter. In Bergey's Manual of Systematic Bacteriology, 2nd edn, vol. 2, The Proteobacteria, part B, The Gammaproteobacteria, pp. 459-463. Edited by D. J. Brenner, N. R. Krieg, J. T. Staley \& G. M. Garrity. New York: Springer.

Bradshaw, L. J. (1992). Laboratory Microbiology, 4th edn. Fort Worth, TX: Saunders College Publishing.

Caton, T. M., Witte, L. R., Ngyuen, H. D., Buchheim, J. A., Buchheim, M. A. \& Schneegurt, M. A. (2004). Halotolerant aerobic heterotrophic bacteria from the Great Salt Plains of Oklahoma. Microb Ecol 48, 449-462.

Dussault, H. P. (1955). An improved technique for staining red halophilic bacteria. J Bacteriol 70, 484-485.

Fendrich, C. (1988). Halovibrio variabilis gen. nov., sp. nov, Pseudomonas halophila sp. nov. and a new halophilic aerobic coccoid eubacterium from Great Salt Lake, Utah, USA. Syst Appl Microbiol 11, 36-43.

Golyshin, Y., Harayama, S., Timmis, K. N. \& Yakimov, M. M. (2005). Genus I. Alcanivorax. In Bergey's Manual of Systematic Bacteriology, 2nd edn, vol. 2, The Proteobacteria, part B, The Gammaproteobacteria, pp. 295-299. Edited by D. J. Brenner, N. R. Krieg, J. T. Staley \& G. M. Garrity. New York: Springer.

González, J. M. (2005). Genus IX. Microbulbifer. In Bergey's Manual of Systematic Bacteriology, 2nd edn, vol. 2, The Proteobacteria, part B, The Gammaproteobacteria, pp. 464-465. Edited by D. J. Brenner, N. R. Krieg, J. T. Staley \& G. M. Garrity. New York: Springer.

Holding, A. J. \& Colle, J. G. (1971). Routine biochemical tests. Methods Microbiol 6A, 1-32.

Ludwig, W., Strunk, O., Klugbauer, S., Klugbauer, N., Weizenegger, M., Neumaier, J., Bachleitner, M. \& Schleifer, K.-H. (1998). Bacterial phylogeny based on comparative sequence analysis. Electrophoresis 19, 554-568.

Ludwig, W., Strunk, O., Westram, R. \& 29 other authors (2004). ARB: a software environment for sequence data. Nucleic Acids Res 32, 1363-1371.

Marmur, J. (1961). A procedure for the isolation of DNA from microorganisms. J Mol Biol 3, 208-218.

Maturrano, L., Santos, F., Rosselló-Mora, R. \& Antón, J. (2006). Microbial diversity in Maras salterns, a hypersaline environment in the Peruvian Andes. Appl Environ Microbiol 72, 3887-3895.

Oren, A. (2002). Halophilic Microorganisms and their Environments. Dordrecht: Kluwer.

Peña, A., Valens, M., Santos, F., Buczolits, S., Antón, J., Kämpfer, P., Busse, H.-J., Amann, R. \& Rosselló-Mora, R. (2005). Intraspecific comparative analysis of the species Salinibacter ruber. Extremophiles 9, 151-161.

Rosselló-Mora, R. \& Amann, R. (2001). The species concept for prokaryotes. FEMS Microbiol Rev 25, 39-67. 
Rosselló-Mora, R., Garcia-Valdés, E. \& Lalucat, J. (1993). Taxonomic relationship between Pseudomonas perfectomarina ZoBell and Pseudomonas stutzteri. Int J Syst Bacteriol 43, 852-854.

Smibert, R. M. \& Krieg, N. R. (1981). General characterization. In Manual of Methods for General Bacteriology, pp. 409-443. Edited by P. Gerhard, R. G. E. Murray, R. N. Costilow, E. W. Nester, W. A. Wood, N. R. Krieg \& G. B. Philips. Washington, DC: American Society for Microbiology.

Sorokin, D. Y. \& Tindall, B. J. (2006). The status of the genus name Halovibrio Fendrich 1989 and the identity of the strains Pseudomonas halophila DSM 3050 and Halomonas variabilis DSM 3051. Int J Syst Evol Microbiol 56, 487-489.

Sorokin, D. Y., Tourova, T. P., Galinski, E. A., Belloch, C. \& Tindall, B. J. (2006). Extremely halophilic denitrifying bacteria from hypersaline inland lakes, Halovibrio denitrificans sp. nov. and
Halospina denitrificans gen. nov., sp. nov., and evidence that the genus name Halovibrio Fendrich 1989 with the type species $H$. variabilis should be associated with DSM 3050. Int J Syst Evol Microbiol 56, 379-388.

Stackebrandt, E., Frederiksen, W., Garrity, G. \& 10 other authors (2002). Report of the ad hoc committee for the re-evaluation of the species definition in bacteriology. Int J Syst Evol Microbiol 52, 1043-1047.

Vreeland, R. H. (2005). Genus I. Halomonas. In Bergey's Manual of Systematic Bacteriology, 2nd edn, vol. 2, The Proteobacteria, part B, The Gammaproteobacteria, pp. 300-313. Edited by D. J. Brenner, N. R. Krieg, J. T Staley \& G. M. Garrity. New York: Springer.

Ziemke, F., Höfle, M. G., Lalucat, J. \& Rosselló-Mora, R. (1998). Reclassification of Shewanella putrefaciens Owen's genomic group II as Shewanella baltica sp. nov. Int J Syst Bacteriol 48, 179-186. 